\title{
Local Tourism, Social Innovations
}

\author{
Tivadar Máhr \\ University of Pannonia, Hungary \\ Zoltán Birkner, PhD \\ University of Pannonia, Hungary \\ Nóra Rodek Berkes \\ University of Pannonia, Hungary
}

\section{Abstract}

Several studies and researches investigate the innovation ability of tourism. The research topic is also interesting, because even the European Union subsidises innovation development and tourism, as a major branch of the service sector, is responsible for the vast majority of the domestic GPPs. Linking these two is an important field of research for a practical perspective as well. The development of technology and ICT harbinger the further advance of tourism. At the same time the question, how such an important branch takes its share of the development of socially important factors, i.e. What answer can touristic stakeholders give to managing current social challenges, can also be raised. Some results of a research conducted in the past year will be presented in the followings. The research question was what social innovation potentials local tourism organizations have, i.e. how their continuous renewal activities help the management of socially important challenges. Factors hindering the innovation of these groups were also researched, along with future innovation plans.

Keywords: social innovation, tourism, innovation JEL classification: $\mathrm{3} 3$

\section{Introduction}

The research is conducted in the cut surface of two popular fields, i.e. tourism and innovation. Both innovation - as the breakthrough for Europe to improve its competitiveness - and the tourism performance are much researched areas in literature.

Innovation policy is typically regulated on a national level in Europe, however innovation still appears on the local level where regional stakeholders are able to establish close ties with each other (Nagy, 2017).

Apart from traditional terms and definitions of innovation social innovation is also important. This field is becoming more and more popular and enterprises feel the responsibility for innovation for the sake of society and the general welfare apart from innovation performances in the classical sense. Tourism, as one of the key factors of national GDPs is also important. One of the main tasks of state-controlled tourism has been the sustainability and improvement of the competitiveness of tourism.

It is thus self-evident how and to which extent one of the main pillars of competitiveness - innovation - appears in the operation of tourism organizations. Who and what needs to be measured to obtain the right picture about the innovation performance of the branch? 
The focus of the research shifted towards the local stakeholders, to those people who get into a real interaction with visitors and it mostly depends on them whether tourists are satisfied, return, or give a positive feedback. These organizations in Hungary are the so called tourism destination management organizations (TDMs henceforward). An inquiry was conducted in the year 2016 among these organizations and $92 \%$ answered questions about innovation performance. This is an almost complete coverage as only 7 of the 79 TDMs did not react. Apart from the classical innovation performance questions were raised about the TDM contribution to the creation of social innovation and the size of the contact-system in which they operate. The media-based, civil contact network is the foundation for the social nestling and thus social innovation. The main focus of the research was the measuring of factors hindering innovation and future innovation plans.

\section{Theoretical framework}

The Horizon 2020 program, as the research and innovation framework of the EU, defines the main pillars on which the economic development of the Union can be built on. Theoretical research must be taken from the laboratory to the business-wise implementation and proper financial frameworks must be provided. Subsequently the Horizon 2020 program is structured on three pillars (Figure 1).

Figure 1

Pillars of Horizon 2020 Program

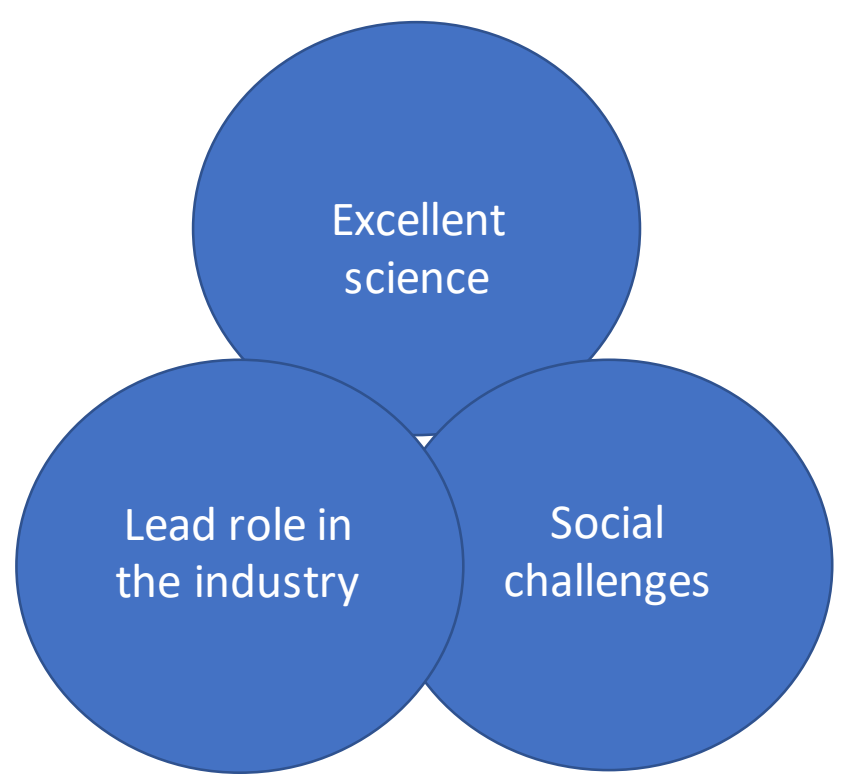

Source: Horizon 2020 (2015)

- Excellent science - aims at enhancing the globally leading role of the EU on the field of scientific excellence.

- Leading industrial role - is meant to found the leading role of Europe on the field of research-development and innovation by means of supporting key technologies, by providing a broader access to capital and by supporting small and medium-sized enterprises. 
- Social challenges - wishes to contribute to the solution of social questions which pose a challenge for all Europe on the fields of healthcare, food security, sustainable agriculture, energy, traffic, climate changes and environmental protection, as well as inclusive, innovative and safe societies.

It is obvious that social challenges enforcing the spreading of social innovation play a major role on the EU level as well (Figure 2).

Figure 2

Distribution of EU 2014-2020 Financial Budget

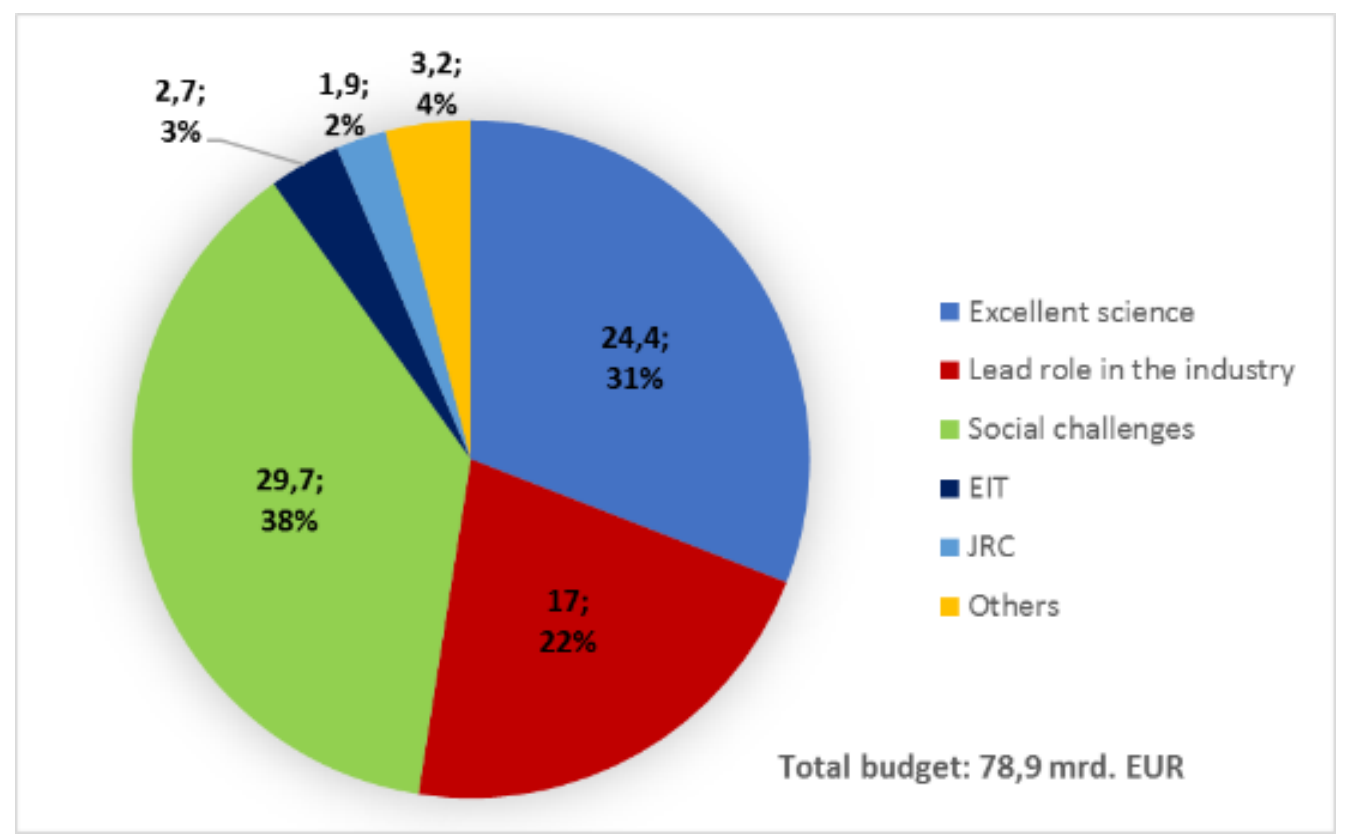

Source: Horizon 2020 (2015)

The creation of innovative communities is formulated at the highest European levels and member countries adapt their regulation systems thereto. The acceptance and the need for novelty is a defining facto in the national economies, thus the development of the innovation ability of TDM organizations, as the main protagonists of tourism, is of special importance for the sake of the future of the entire branch (Máhr, 2017).

The term of social innovation was first mentioned at the beginning of the last century and it mainly has sociological roots. It was defined as the social impact of innovation and the social aspect leading to innovation. According to de Tarde (1899) societies exist as expanding economies which have internal connections and these lead to the existence of innovation. Hoggan (1909) is the first to mention social innovation. At that time one could not speak about a theory, only about the mentioning of the term. Further definitions were created in the past 30 years and the need for the scientific research was strongly felt:

- The role of civil organizations in the development and conveying of solutions given to social problems.

- New social relations result in social impact (e.g. innovations in caring for the elderly people in their homes)

- New social connections come to life in the wake of new solutions (e.g. the inclusion of the music industry against famine)

- Society must change to the new technologies (the behavior of society must change in order to introduce technical innovation). 
Social innovation became a theory in the year 1999. The term of social innovation capital and the highlighting of the necessity of social interactions to create new ideas appear. It is also pointed out that technological innovation cannot take place without social renovation.

The years 2004-2008 brought along the forming of various theories, while in the past years researchers make differences in the conscious perception. (Design thinking, normative approach, differentiating from the technological innovation). Also the political aspects of the explanations and approaches strengthened and the question of the generation of social innovation is a new form of the affluent society arises.

The road from the first mentioning to it becoming a conscious theory was long and all in all it can be said that social innovation has a social impact. The idea of innovation originates partly from social organizations and new forms of cooperation are created in the development and implementation.

The innovation-theoretical researches of the past years provide the space for new theoretical approaches. Birkner et al. (2016) derives the appearance of social innovation from the helix model of the innovation systems.

Birkner et al. (2016) believes that the appearance and scientific acceptance of the third and fourth helix model is the birth of the term and research of social innovation.

The importance of researching social innovation cannot be neglected today, as the scarce national and natural resources require the rational use of investable goods, a bigger social and economic efficiency and efficacy. There is a growing need for a top-down (coming from the state) initiatives and bottom-up solutions pointing towards the development of the society. Social innovation develops so far unused innovative activities and new services - as a reflection to the needs of local communities and the civil society. There are several examples hereof:

- neighborhood services (babysitting, caretaking)

- associations

- fair trade movement for bolstering sustainable development

- community courts

- online counselling, assistance

- online healthcare assistance groups

Despite these examples minor attention was paid to the process of social innovation, but the practical solutions based on its results are slowly gaining their raison d'etre. The challenge is ever bigger and several social problems await an innovative solution:

- Consequences of the challenge of the aging society

- The impact of digital cleft on the generations

- Differences between settlements - mainly infrastructural differences

- Value and self-evaluation crisis

- Deterioration of the quality of life (obeseness, lack of movement, addictions, widespread diseases)

- Climate changes, environmental protection

- Youth starting their lives

- Creating the connection between traditional values and technologydevelopment

There are more and more initiatives in the world:

- Outsourcing of social innovators and helpers

- Treating the problem of the ageing society by means of ICT tools

- Best practices of community services reflecting on the local needs 
- The "broken window" - what science- and activity-based nodes and community initiatives can stop the brain-drain, impoverishment and deterioration?

The overview of the work of researchers in this field results in various definitions. One of the tasks of social innovation is to solve new social and environmental problems created in the wake of socio-economic changes by social means (Szörényiné, 2015). Mulgan et al. (2007) believe that social innovation is a series of innovative activities and services which serve the satisfaction of certain social needs which are spread and developed by organizations whose primary objective is the social well-being.

The aim of social innovation is the reaching of a higher life-standard which can be implemented by increasing the level of employment and the improvement of the conditions of public safety and environment (Kocziszky et al. 2017).

Nemes et al. interpret the existence of social innovation via clearly new mechanisms as the science-based technological innovation. Its creation is favored by social interactions which are innovative in themselves (social learning, cooperation, networking, exchange of experience, etc.). In a broader sense new and unusual perspectives and approaches, paradigms, products, processes and practices aimed at solving the arising social needs and problems, while new values, attitudes, connections or new structures emerge, can be regarded as social innovation (Nemes et al., 2015).

Figure 3

The Tight Relation between Economic and Social Innovation

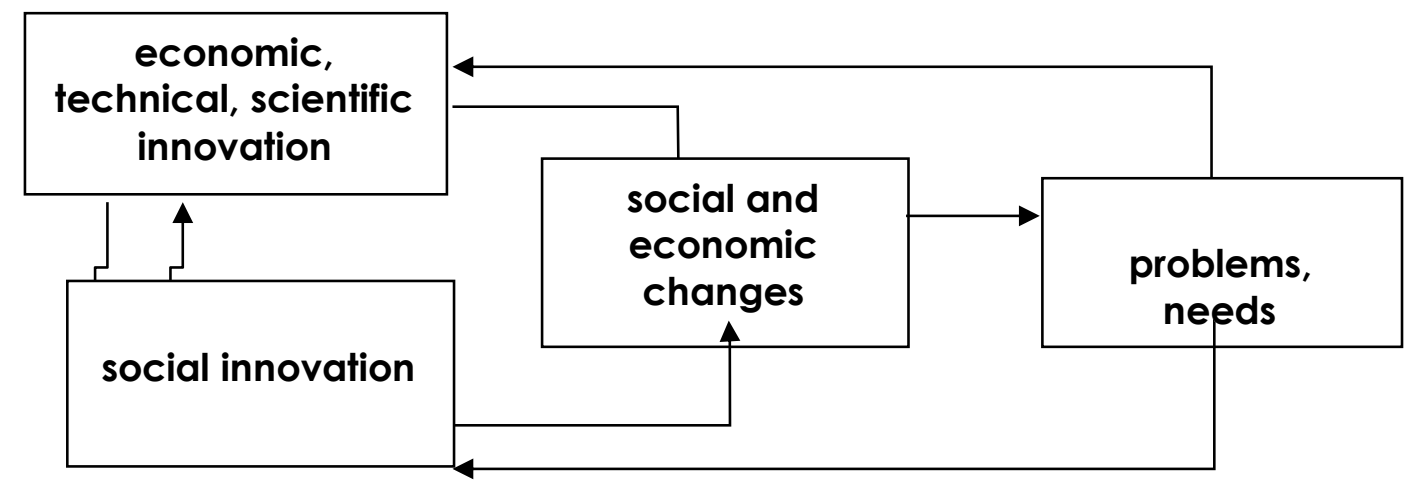

Source: Benedek et al., 2015

According to the research of Benedek the real difference between social and economic innovation are in the aim of innovation and the capital demand, however, there is a strong connection between them (Figure 3). The authors (Birkner et al., 2016) accept this by completing the thought that enterprises are major elements of this sphere and they take a major role in creating traditional (economic, technical, natural sciences-related) innovation and their activities are influenced by the following factors (human resources, money, degree of development of R+D) as well as the existence of relations to main protagonists defining social innovation (civil society, local communities).

Social innovation expresses the extra-power in the community which can contribute to the management of the problems of a settlement from own sources (Kocziszky et al., 2015). 
Social innovation is thus getting more and more into the center of the attention. The objective of the aim defined in the Horizon 2020 program is the efficient use of resources. It was worth to restructure the organizational and legal framework system on the state-level and the Social Innovation Council was created in Hungary in the year 2017. The task of the organization is to provide the vocational background for the calls aimed at social innovation in the EU budget-period of 2014-2020.

Thus the problem of the research is the innovation performance of TDM organizations and the social fields on which they could show innovation. The connection network of the organizations, which is the basis of their social embedding and through the basis of social innovation, is being investigated. TDMs appear in the present approach as civil, media-based organizations on the touristic market, but they also have market-oriented activities. Therefore they are regarded as SMEs from this perspective.

The aim of the research was the analysis of the question raised in connection with the above-mentioned problem and the analysis of the data received and the drawing of conclusions.

Hypothesis

$H$ : TDM organizations are able to show social innovation and have wide-spread connection networks.

\section{Methodology}

The work is built on a primary research which was conducted in form of a query conducted on the years of 2016-2017. The authors planned an inquiry which would cover Hungary and as a result 72 TDM organisations out of the total of 79 gave answers. Apart from the questions aimed at innovation organisational and structural characteristics were measured. This document presents the results related to social innovation, the factors hindering innovation and the measurement of the future innovation plans.

\section{Results}

Figure 4 shows the answers given to the question related to the cooperation network. The investigation of the cooperation was grouped alongside the triple helix model: the existence of contacts to the universities (according to the authors the science and thus not only the university links were put in this group), the economy and to various protagonists of the government was researched. It is typical that TDMs establish contacts to secondary and tertiary education, while it is not typical that they have contacts to vocational organizations in the economic coordination, or chambers. Various governmental organizations have a strong influence and this is especially true for the cooperation with local governments and the state tourism management (the Hungarian Tourism Holding ceased to legally exist after the research, but the Hungarian Tourism Agency was formed instead). The influence of local governments matches the picture that self-governments have a membership, or ownership in TDMs and thus there is a strong need for cooperation. Regarding the social innovation potential it can be said that TDMs cooperate and this cooperation van is the foundation of the development of social innovation and this is especially true for innovations which are important from the point of view of the government as well. 
Figure 4

Cooperation Network of TDMs

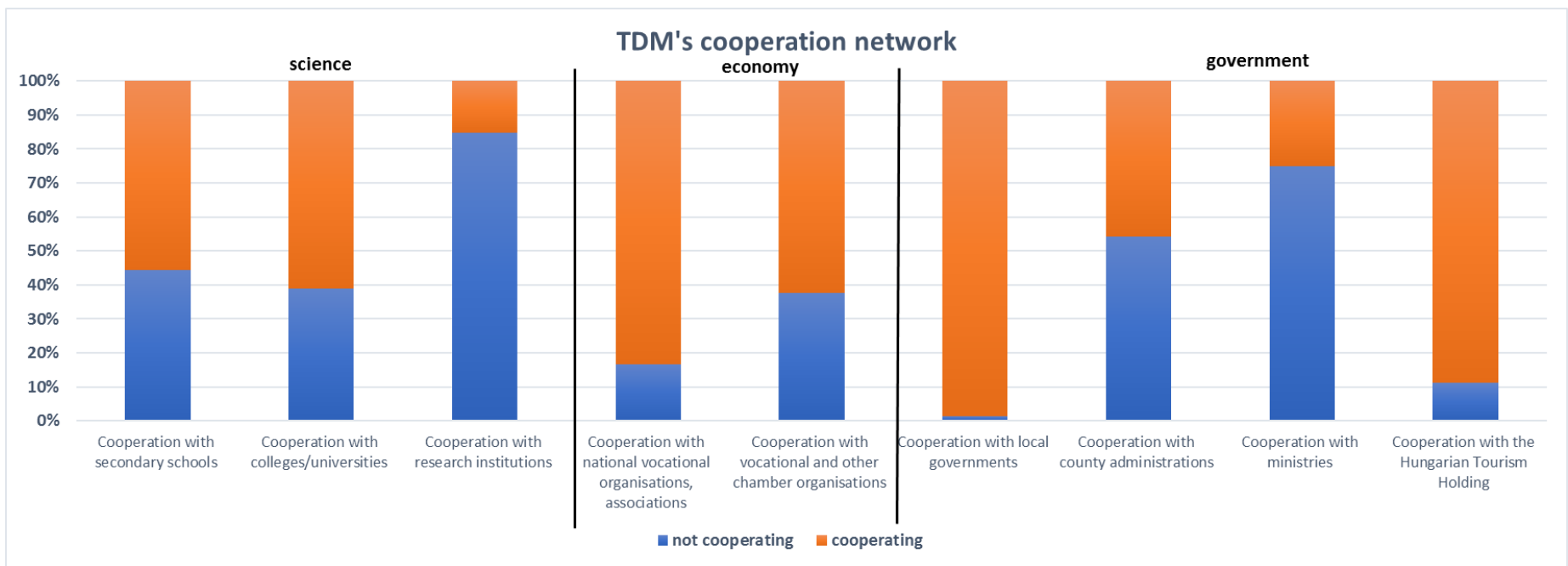

Source: Authors' work

The contact system of TDMs to other civil organizations was also researched. The question of how many active contacts are there to civil organizations was answered by an average of 7.6. This could be regarded as a proper activity, but it must definitely be considered that it is the TDMs which should have a broad network of connections as they are the driving force of and behind the local touristic life.

It is however more lucrative to look behind the mean values. The contact system of $68 \%$ of TDMs is below average and only 11 TDMs have more than 15 active civil connections (Figure 5).

Figure 5

TDM's civil connections

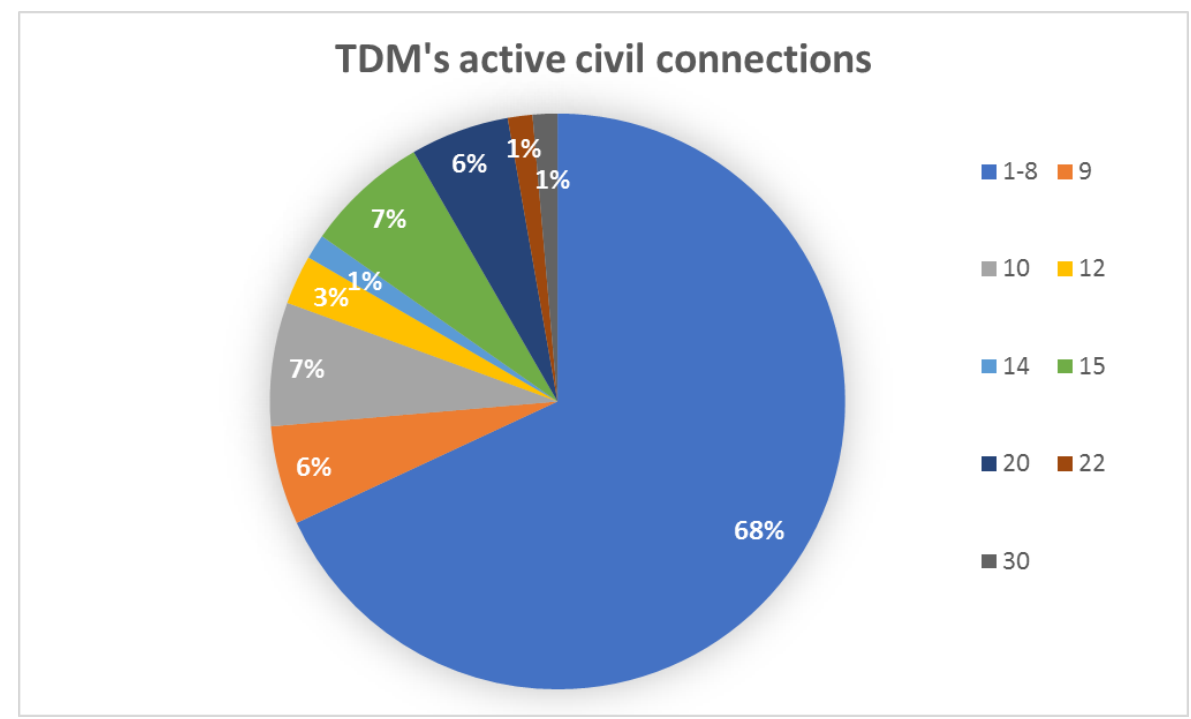

Source: Authors' work

Carayannis et al. (2012) created the quadruple helix model by thinking the above mentioned triple helix model further and their fourth helix is the media- and culturebased community space and the civil society. Thus it is obvious that the members of 
society and the communities are linked to the business, technology, service and scientific areas and therefore the civil and public spheres are also linked to the context system of the triple helix (Birkner et al. 2016).

The size/depth of the contact system and the cooperation network can help the development of social innovation. The next graph shows the social innovation activity of TDM organisations (Figure 6).

Figure 6

TDM's Social Innovation Activities

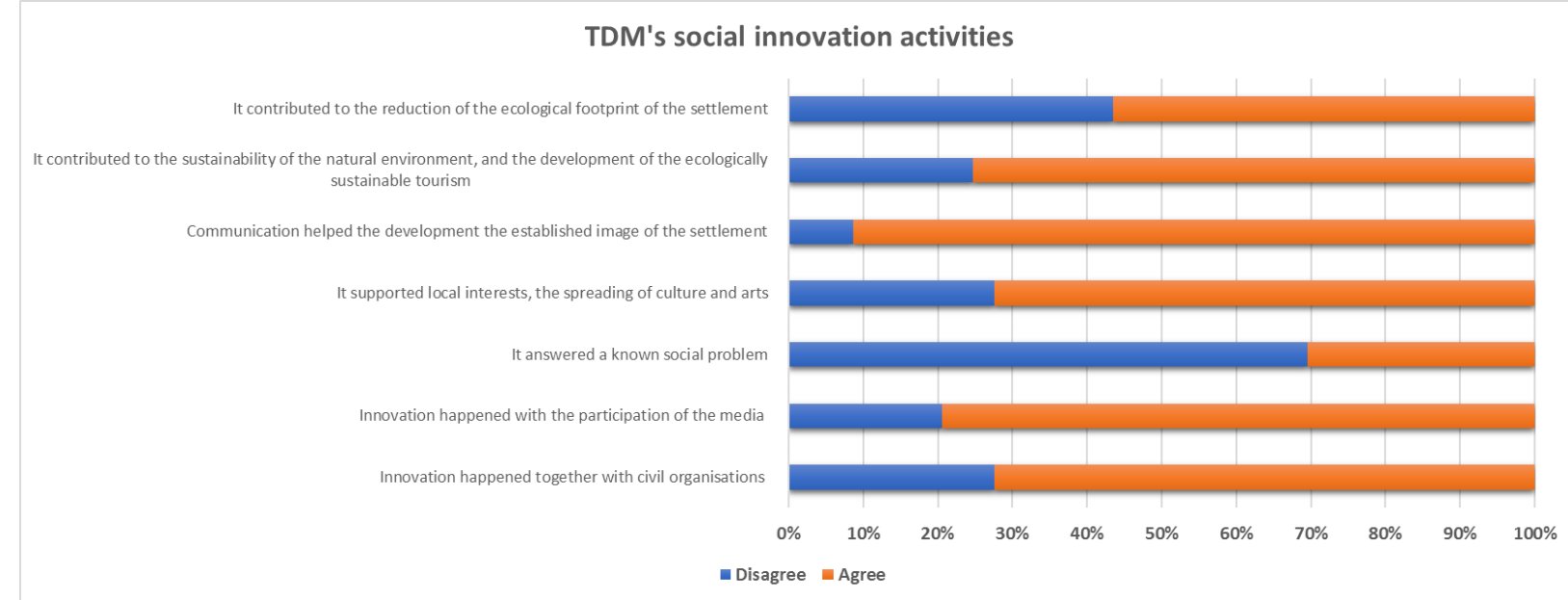

Source: Authors' work

The graph shows some typical aspects of TDMs. The task of reducing the ecological footprint and the question of environmental sustainability rather point towards preserving, protecting the environment and environmental sustainability. It can be seen that TDMs did their part in the environmental sustainability. The communication of TDMs could increase their image and supported the development of the local public life, culture and communication. They cooperated with the media and various civil organisations. In $30 \%$ of the cases they were able to provide some innovation for social problems. All this means that TDMs have the possibility of developing social innovation within their own field of operation.

The research also analysed the hindrances of innovation, i.e. those factors were researched which hindered the innovation performance. This can be seen on the next graph (Figure 7). 
Figure 7

Hindrance of Innovation

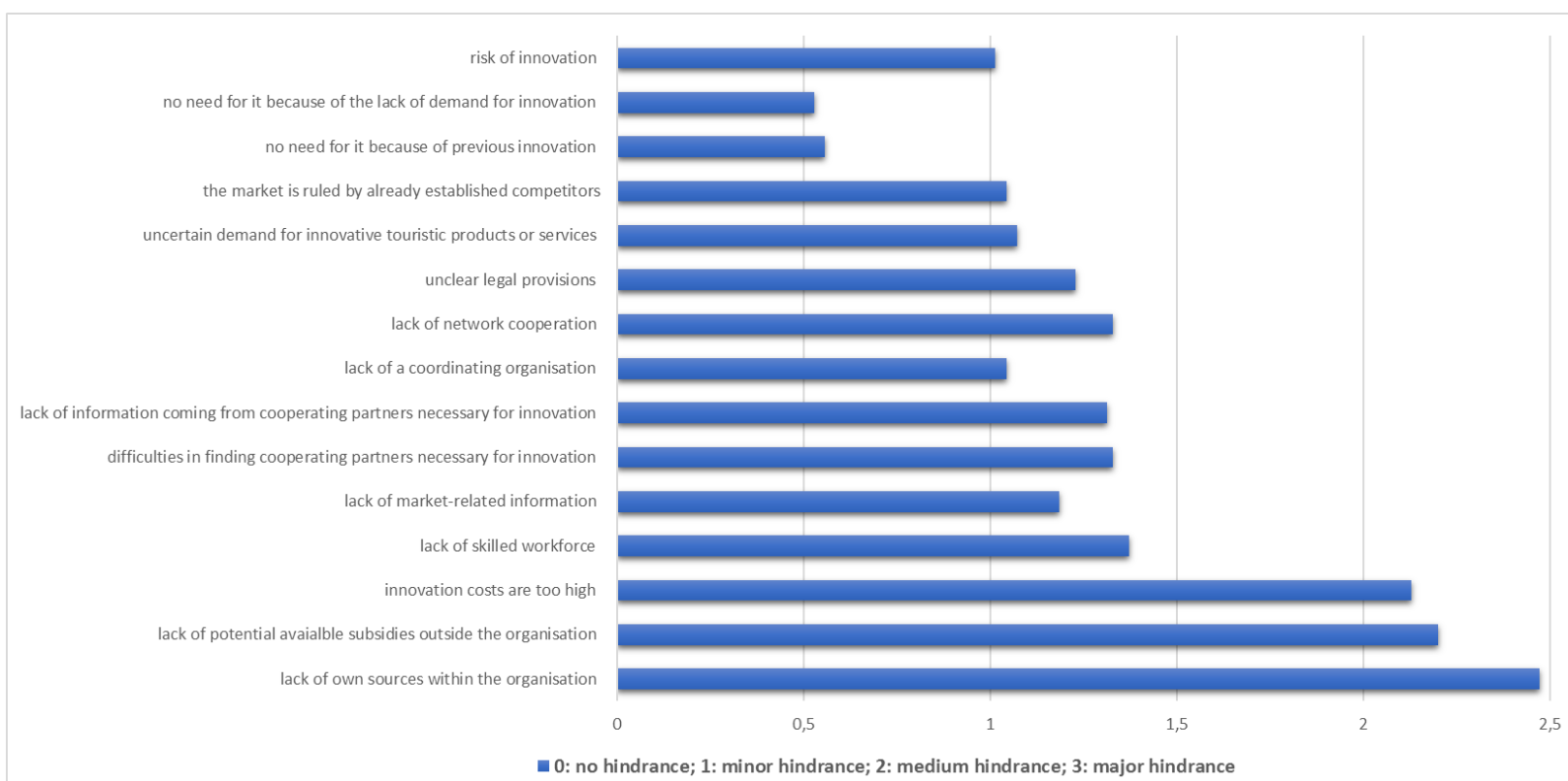

Source: Authors' work

TDMs see the main hindrance of innovation development in the financial resources. This can be a reason for hope, because if there are financial resources (this is evidently the task of the state tourism management and the government) the TDMs are ready to develop.

The next chart about the future plans of the TDMs undermines this.

They are ready for developments on various fields (HR, product, processes, ICT, marketing) (Figure 8).

Figure 8

TDM's future plans

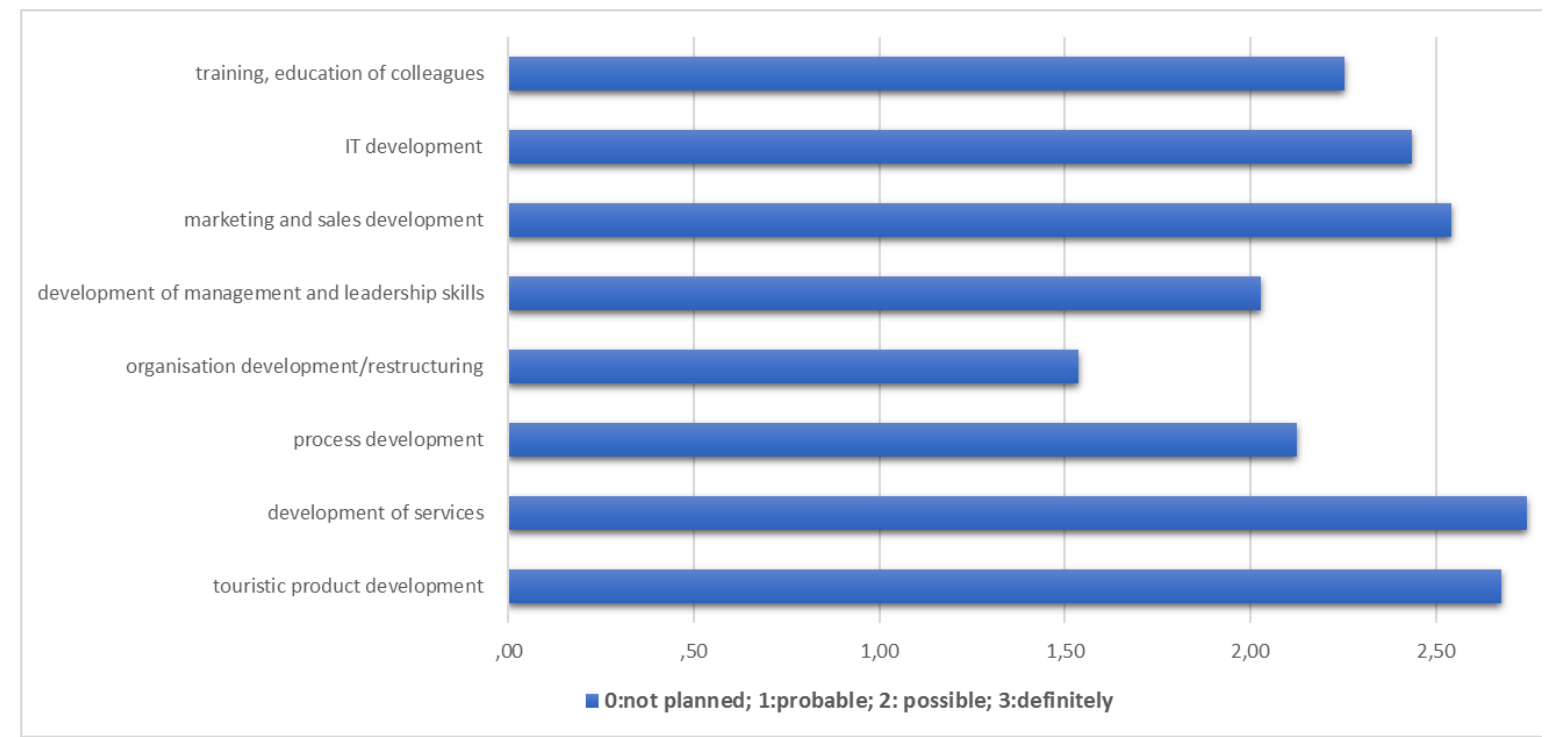

Source: Authors' work 


\section{Discussion}

The paper analyzed the social innovation activity of TDM organizations and researched the important social fields on which these organizations showed innovation. The analysis of the contact network showed the degree of social embedment and thus the readiness for social innovation. The hypothesis was that local tourism organizations are capable of social innovation.

TDMs usually cooperate well in the triple helix of science-economy-government. They cooperate well with local or county-level state organizations from the government segment. This is understandable as the TDMs are present as local groups and their contact systems do not expand towards the national government. Results are achieved with a small number of contacts and it can be assumed that TDMs in small settlements use all their possibilities and can thus build a limited amount of contacts in their micro-regions. TDMs participate in the development of social innovation by including the media and various civil organizations into their operation and they were successful in spreading arts, culture and the common interest. Scarce financial resources limit the creation of innovation, but they have plans in their own segment for the coming era.

The hypothesis is seen as approved and the authors would like to draw their attention to the fact that TDMs, as the centers of local tourism, play an important role in developing the local social networks.

\section{Conclusion}

In this paper the social innovation activity of TDM organizations and their related future plans and the factors hindering innovation were analyzed. The size of the sample shows an almost complete coverage, thus the conclusions are properly founded. The field of social innovation has a special importance both in literature and the practical life. The social challenges which mankind has to face require innovative performances and thinking.

The research compensates for shortcomings in a way that touristic organizations are considered from two perspectives: on one hand as media-based civil organizations and on the other as SMEs which are responsible for managing challenges that society has to face. Innovation is the foundation for development in tourism, thus the innovation performance of TDMs must be valued and the results are informative for the TDMs (too). This can be regarded as a milestone in the development of TDMs, as answers to social challenges can only be produced via development and learning.

The main conclusion of the paper is that social innovation is not only a "byproduct" mentioned alongside classical innovation analyses and performances, but an individually interpretable area which indeed has a role in literature. It is a segment that can be interpreted by local tourism organizations which is a major element of the media-based, civil cultural field. The social activity of the TDMs is remarkable and the hypothesis of the research was accepted.

Regarding the limitation of our paper, the query conducted among Hungarian TDMs was almost all-covering, but a European perspective is definitely worth considering in order to analyze the social innovation results of tourism, to draw conclusions and to find and spread best practices.

\section{References}

1. Benedek, J., Kocziszky, Gy., Veresné Somosi, M., Balaton, K. (2015), "Regionális társadalmi innováció generálása szakértői rendszer segítségével" (Generating 
Regional Social Innovation with the Help of a System of Experts), Észak-magyarországi Stratégiai Füzetek, Vol. 12, No. 2, pp. 4-22.

2. Birkner, Z., Máhr, T. (2016), "Interpreting innovation - in another way" Vezetéstudomány/Budapest Management Review, Vol. 47, No. 10, pp. 39-50.

3. Carayannis, E. G., Campbell, D. F. J. (2012), Mode 3 knowledge production in quadruple helix innovation systems, Springer, New York, NY.

4. de Tarde, G. (1899), Social Laws: An Outline Of Sociology, Forgotten Books.

5. Hoggan, F. (1909), "The American Negro and Race Blending", The Sociological Review Vol. a2, No. 4, pp. 349-360.

6. Horizon 2020 (2015), available at: http://www.h2020.gov.hu/horizont2020-program (1 1 August 2018)

7. Kocziszky, Gy., Veresné S. M., Balaton K. (2015), "Társadalmi innováció mérésének sajátosságai -tanulmány/kutató munka a TÁMOP-4.2.1.D-15/1/KONV-2015-0009 azonosító számú projekt részeként" Characteristics of Measuring Social Innovation Study/Research Work as a Part of the Project with the ID TÁMOP-4.2.1.D-15/1/KONV2015-0009.

8. Kocziszky, Gy., Veresné S. M., Balaton K. (2017) „A társadalmi innováció vizsgálatának tapasztalatai és fejlesztési lehetőségei" (Experiences of Analyzing Social Innovation and its Development Possibilities), Vezetéstudomány/Budapest Management Review, Vol. 48, No. 6-7, pp. 15-19.

9. Máhr, T. (2017), "Developing Touristic Destination - Innovation Performance Issues", Interdisciplinary Description of Complex Systems: INDECS, Vol. 15, No. 1, pp. 49-65.

10. Mulgan, G., Tucker, S., Rushanara, A., Sanders, B. (2007), Social innovation - What it is, why it matters and how it can be accelerated?, Said Business School, University of Oxford, Oxford.

11. Nagy, J. (2017), Társadalmi innováció a pannon városokban (Social Innovation in the Pannonian Cities), Felsőbbfokú Tanulmányok Intézet, Kőszeg.

12. Nemes, G., Varga, Á. (2015), "Társadalmi innováció és társadalmi tanulás a vidékfejlesztésben - sikerek, problémák, dilemmák" (Social Innovation and Social Learning in Rural Development - Successes, Problems, Dilemmas), in „Mérleg és Kihívások" IX. Nemzetközi Tudományos Konferencia, Miskolci Egyetem Gazdaságtudományi Kar, pp. 434-444.

13. Szörényiné, I. K. (2015), "Vidéki térségeink innovációł befogadó képessége - Egy kutatás tapasztalatai" (Innovation Acceptance Capacity of Rural Areas - Experiences of a Research), Tér és Társadalom, Vol. 29, No. 1, pp. 97-115.

\section{About the authors}

Tivadar Máhr is an active settlement development specialist, tourism and innovation expert, the vice-mayor of a highlighted touristic destination and PhD student in Management and Business Administration at the Doctoral School of University of Pannonia. The author can be contacted at mahrtivadar@gmail.com.

Zoltán Birkner, $\mathrm{PhD}$ is an associate professor at University of Pannonia Nagykanizsa Campus, a research specialist in the field of innovation performance of companies and regions and the manager of a water technology research and development center. The author can be contacted at birkner.zoltan@uni-pen.hu.

Nora Rodek Berkes is a lecturer at University of Pannonia Nagykanizsa Campus. She is a PhD student in Management and Business Administration at the Doctoral School of University of Pannonia. Her research topics are CSR (Corporate Social Responsibility), sustainable and responsible management, social innovation. The author can be contacted at rodek.nora@gmail.com. 